\section{REQUESTS FOR ASSISTANCE}

The Blue Jay has recently been declared the avian emblem of Prince Edward Island. We are anxious to obtain high quality photos of the bird for use in publications, interpretive slide talks and related projects. Do you have any suitable photos that we can purchase? If so, please contact Diane Griffin, Supervisor of Interpretation, Dept. of Tourism, Parks and Conservation, P.O. Box 2000, Charlottetown, Prince Edward Island C1A 7N8.

A comprehensive bibliography of martins is currently in preparation. It will include all papers dealing solely or partly with martins (Progne spp.) except local annotated checklists. Authors wishing to have material included should send an abstract or reprint to Charles R. Brown, Box 1309, Austin College, Sherman, Texas 75090, USA.

I am working with volunteers from the Manitoba Naturalists Society on an index to the Chickadee Notes column of A. G. Lawrence, numbers 1-1756. We would like to include the location of all known complete or nearly complete sets of the columns to facilitate access to this valuable source of information on the birds of Manitoba and adjacent regions. Anyone having all or most of these columns or knowing of someone who may, please write Jack Dubois, Assistant Curator, Manitoba Museum of Man and Nature, 190 Rupert Avenue, Winnipeg, Manitoba R3B 0N2.

The National Museum of Natural Sciences in Ottawa is developing a permanent exhibit gallery entitled ANIMAL GEOGRAPHY, and is looking for high quality colour photographs of specific subjects. If you have photos you think might be suitable on the following subjects a) $35 \mathrm{~mm}$ (or larger) colour transparencies or negatives of Greater Prairie Chicken or Sage Grouse (typical habitat, noncourtship poses), or of desert habitat (sandy desert or dune bounded by a line of vegetation)

b) large format (2 $1 / 4$ or larger transparencies capable of beins enlarged to $4^{\prime} \times 4^{\prime}$ of man alterec environment (a smoggy cityscape industrial area, garbage dump etc.), cowboy and cattle (an actior shot of cowboy rounding up cattle or a pastoral scene of a shepherc and dog watching over sheep) predator and prey (a predato such as a lynx, coyote, bea catching or eating a prey such as rabbit, salmon, etc.);

please send a copy to the addres below. We will negotiate paymen and credit for use of photos selected Those photos that do not meet ou specifications will be returned b registered mail. Barry Peers, Exhibi Planner, Interpretation \& Extensior Division, National Museum of Natura Sciences, Ottawa, Ontario K1A 0M8

\section{SNHS ANNUAL MEETING}

The 29th annual meeting of the Saskatchewan Natural History Societ will be held in the Biology Theatre or the Campus of the University 0 Saskatchewan, Saskatoon, on Oc tober 14-15, 1977.

Registration will begin at 1830 of Friday. Members are invited to pre sent up to five minutes of slides Saturday's banquet will be in Marqui Hall, near the Biology Building.

Please send resolutions to $\mathrm{Dr}$ Maureen DuWors, Biology Depart ment, University of Saskatchewan Saskatoon, in advance of the meeting

\section{YOUNG NATURALIST SECTION FOR NEWSLETTER}

Editor Pat Kern invites contri butions from young naturalists for special page in the SNHS Newslette She would welcome nature obse! vations, poems or sketches an drawings suitable for black and whit reproduction. Send them to 105 Chestnut Avenue, Moose Jaw Saskatchewan S6H 1A7. 